\title{
REACHING THE UNDERSTANDING OF THE GREEN BUILDING CONCEPT IN ISLAMIC VALUE: THEMATIC TAFSEER STUDY
}

| Received June 28th, 2021 | Accepted September 14th, 2021 | Available online December 15th, 2021 |

| DOI http://dx. doi. org/10.18860/jia.v6i4.12742 |

\section{Aulia Fikriarini Muchlis}

Institut Teknologi Bandung

Indonesia

auliafikriarini@arch.uin-malang.ac.id

\section{Dewi Larasati}

Institut Teknologi Bandung

Indonesia

dewizr@ar.itb.ac.id

\section{Sugeng Triyadi}

Institut Teknologi Bandung

Indonesia

sugengtriyadis@gmail.com

\begin{abstract}
This research is significant to fill the gaps in the development of green building concepts that give an emphasis to the technical strategies or solutions. This study used the thematic Quranic interpretation method (maudhu'i). It was done by collecting verses from the Quran related to the environment in general, specifically using quantitative content analysis. The result shows that there are two significant main categories stated for greenship based on thematic, mainly ASD and WAC. It reaches the most vital points. It is $56.1 \%$ points of ASD and $28.5 \%$ of WAC. It is expected that, by applying this approach, the green building concept will be much easier to be accepted, understood by human being as caliphs, and implemented as well as possible.
\end{abstract}

\section{KEYWORDS:}

Green Building; Religious Values; Sustainable Development; Thematic Tafseer

\section{INTRODUCTION}

The idea of a sustainable development is considered as response to what society needs in balancing the environmental protection by considering the social and economic aspects. By using this framework, the buildings are actualized to give the good influences for the environment and human being [1]. The World Commission on Environment and Development (1987) / Brundtland Report defines the sustainable development as a development reaching what is needed nowadays without decreasing the ability of further generations to fulfill their needs. This concept of needs emphasizes the needs of the poor in the world and others, which are caused by the environmental limitation to provide and meet the current as well as future needs [2]. In line, sustainability can be seen as an equitable distribution and a share of capacity for the prosperity of current and future generations [3][4]. It includes the increasing living standards for the human population, health, adequate dwelling, and welfare for every single person [5]. From the Islamic perspective, sustainable development refers to the presence of a moral interaction between humans and the environment to attain the unity and the balance. (al-tawazun) [6].

Agenda 21 is an international blueprint that defines sustainable development so that all levels of society may implement it following their local environment. The agenda in agreement 21 includes the viewpoint that people are seen as an intrinsic component of the world's nature (biosphere). Therefore, there should be no damaging activity or pollution on the environment and everything in it anymore.

In Indonesia and other nations, the efforts to achieve the sustainable development are implemented using a green building method. Green rating systems discussed in the research [7] focus on green building project delivery and development, green building certification and rating [8],[9],[10],[11], energy performance [12], advanced technologies, and also the adjustment of the green rating to the local context [13],[14],[15]. However, it appears that public knowledge and understanding of green buildings are still low. It has not reached all sectors of society yet, resulting in less-than-optimal green building implementation (Breaking through the Barriers to Green Building Movement in Indonesia: Insights from Building Occupants). Furthermore, successful green building installation is needed to be complemented by the ecologically responsible conduct on the part of building users. Several studies had identified the challenges and obstacles [14],[15], [18],[19],[20],[21], [22] in implementing the green building idea, implying that green buildings in developing nations, particularly Indonesia, has not been effectively implemented.

Therefore, the purpose of this research is to look into religious views on the environment, particularly those which are the most closely related to the notion of green architecture. This method is used to help people to realize the importance of the green construction concept for the planet's long-term viability. Furthermore, these religious beliefs are closely associated with Indonesian social culture, 
which is prioritizing religion to guide life. This study is necessary because religious principles have a favorable impact on environmentally conscious behavior, such as caring for the environment and developing good habits [23].

\section{GREEN BUILDING CONCEPTS BASED ON THEMATIC TAFSEER}

The concepts of sustainability and sustainable development are discussed and analyzed from different theoretical perspectives. This study will examine the concept of green buildings from an Islamic perspective, which seeks to explore the verses of the Quran. Islam is a religion that promotes the link between humans and their environment, and it penetrates human territory as the caliphs on earth [24]. As the primary source of Islamic teachings, which is believed and acknowledged to be accurate, the Quran contains teachings concerning religious concepts, ethical, and spiritual ethics [25]. It also has rules for various aspects of daily life that should be known and understood by humans to overcome all problems in the world, including environmental issues. We can capture the contents of the Quran through verses that are interpreted as signs, symbols, or proof of the divine. A verse is a reading material composed of several sentences having a beginning and an end, which is comprehensively summarized in one surah.
Next, the approach for Quran interpretation chosen for this study was the maudhu'i (thematic) approach. The main feature of this method is highlighting the theme, title, or discussion topic by compiling all the verses of the Quran related to the theme. The word maudhu'i is derived from Arabic that is maudhu'. Thus, the maudhu'i interpretation can be understood as an explanation of the Quran verses regarding a particular title or topic of the conversation. This thematic Tafseer triggers an effort to interpret the Quran regarding specific terms by collecting all or some verses that can represent and explain the entire verses as a unity to obtain the complete answers or Quran perspectives about specific terms. Therefore, this thematic study helps to find an Islamic view regarding the environment and the theme of green buildings. The interpretation used in this study is the Thematic Tafseer of the Quran regarding Environmental Conservation issued by the Agency of Research and Development, Education and Training of the Ministry of Religious Affairs. In detail, figure 1 depicts five important subjects relating to environmental preservation: humans, water, clouds and wind, plants and trees, and environmental cleanliness.

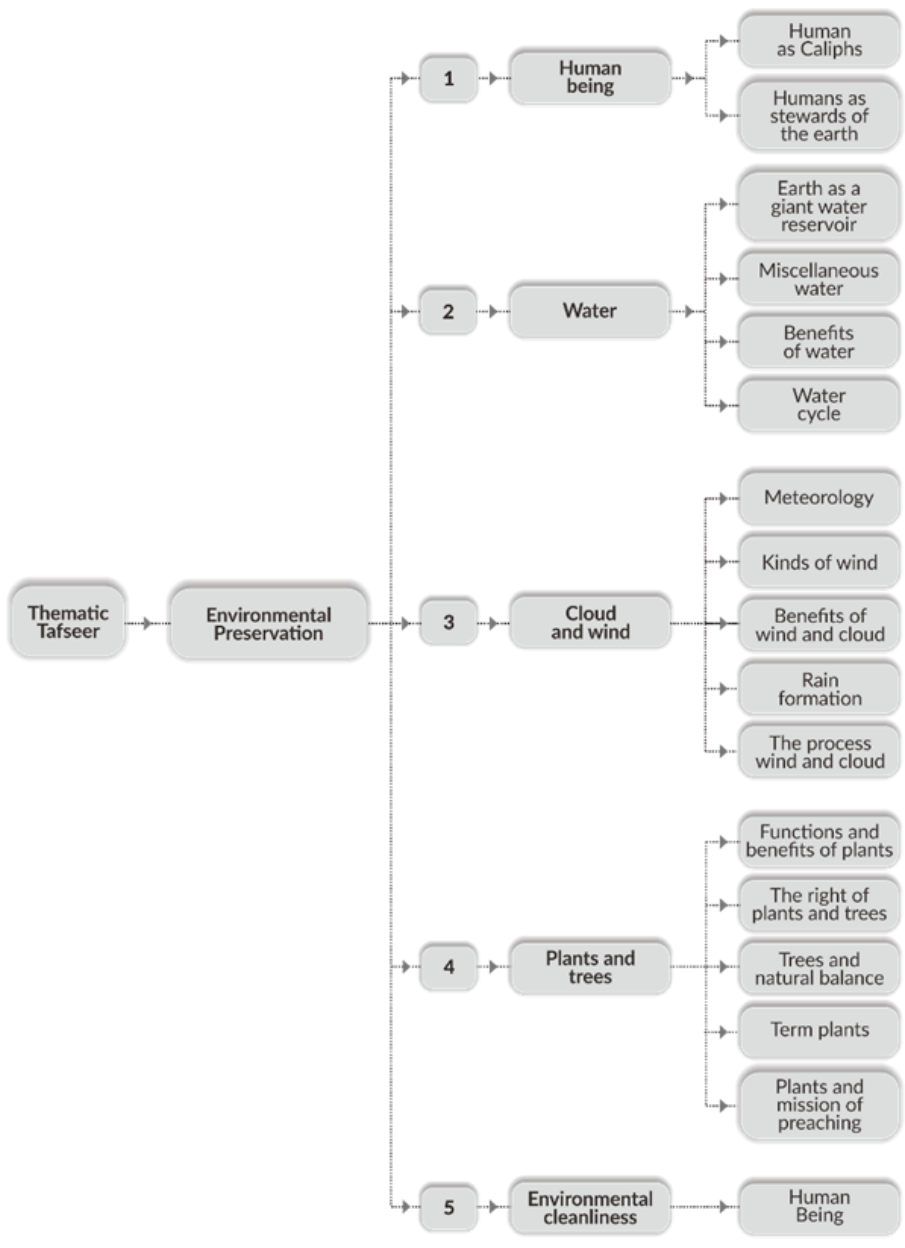

Figure 1. Environmental Preservation in Thematic Tafseer 


\section{METHOD}

This study used a content analysis approach to describe and examine the contents and meanings contained in the Quran as derived from thematic Tafseer. Content analysis is the process of a logical interpretation of the text taken from the Quran to produce a precise, systematic, and quantitative depiction without forgetting the context of the study. This content analysis would explain a particular theme, so the results could be generalized to find the characteristics of the content and to make an inference. The results of the content analysis were referred to as keywords.

\section{THEMATIC TAFSEER DATA}

Content Analysis of the five sub-themes in figure 2 produces the most numerous keywords in the "Plants and Tree" sub-thematic, which are 25 kinds of keywords with a total of 135 keywords. The sub-theme concerning the plants is often described in the Quran and is significant compared to another sub-theme. The "Water" and "Wind and Cloud" sub-themes have almost the same type and number of keyword types as well as the total number of keywords. The last subthemes with the least number of keywords are Human Being and Environmental Cleanliness.

Some keywords from each sub-theme have similarities; therefore, to avoid repetition, the keywords from the

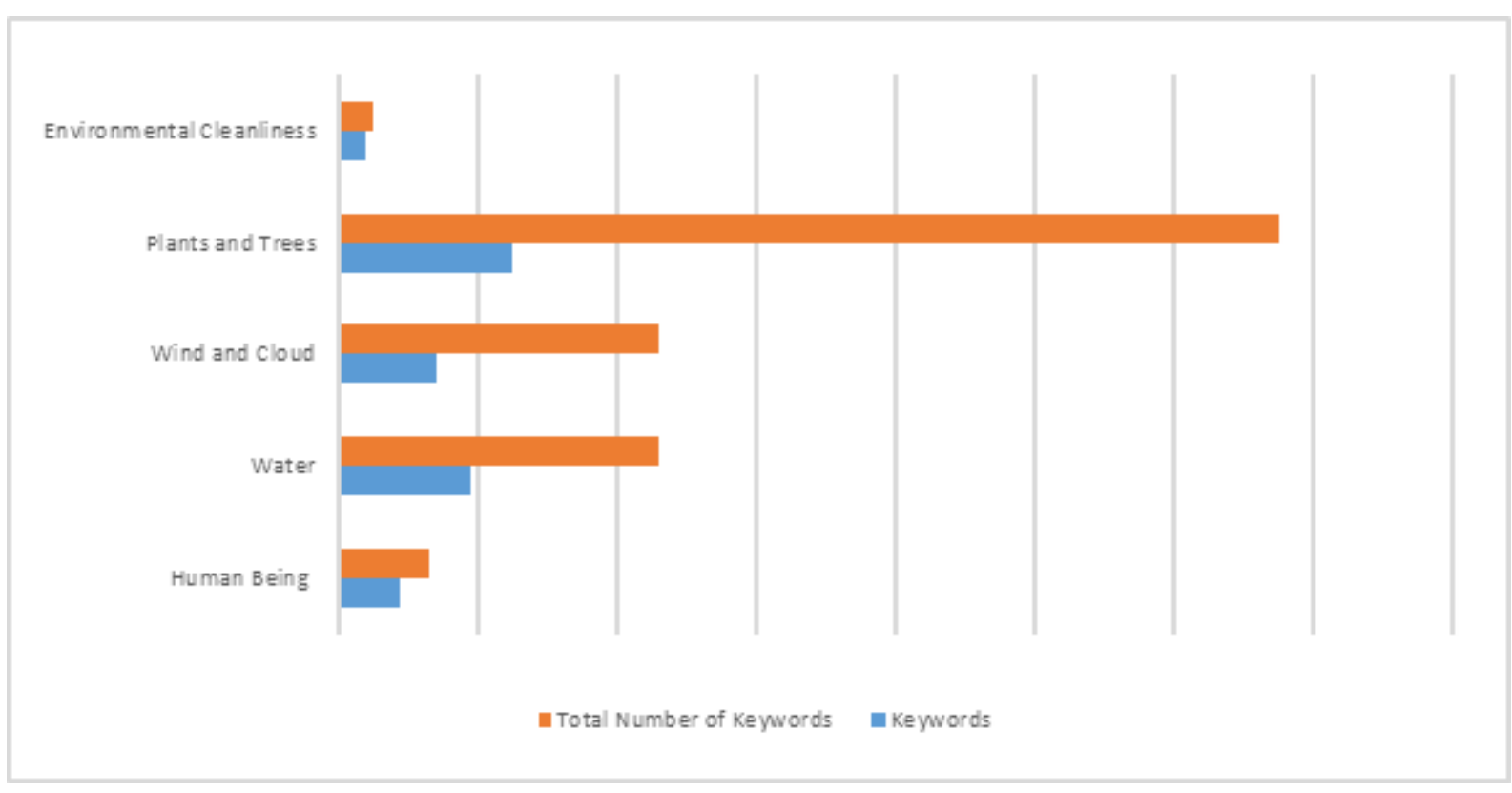

Figure 2: Number of Keywords per topic (Results from Content Analysis)

whole sub-themes are merged into one, as shown in figure 3. The highest number of keywords are fruits (39), rainwater (35), benefits of rainwater (23), tree (23), garden (12), and 11 numbers of each keyword, namely clean water, wind, grains, and plants. These keywords are then used in the next stage, which aims to categorize greenship criteria based on thematic Tafseer. The next stage of this study is categorizing the thematic verses of the Quran using the green building concept of $\mathrm{GBCl}$ as the theme. The sub-thematic results and discussion will show the surah and verses of the Quran related to the sub-theme. The sub- thematic compilations in figure 4 show the major surah, 32 surah, and 52 verses mentioning Plants and Trees. Nine surah and 20 verses mention the plant's functions and benefits, and eight surah and 12 verses mention Plants and missions of proliferation. Overall, the number of surah in each sub-theme is 5-9 letters, and the rest are only 1 to 2 letters. The sub-themes of plants and trees are very dominant compared to other sub-themes. 


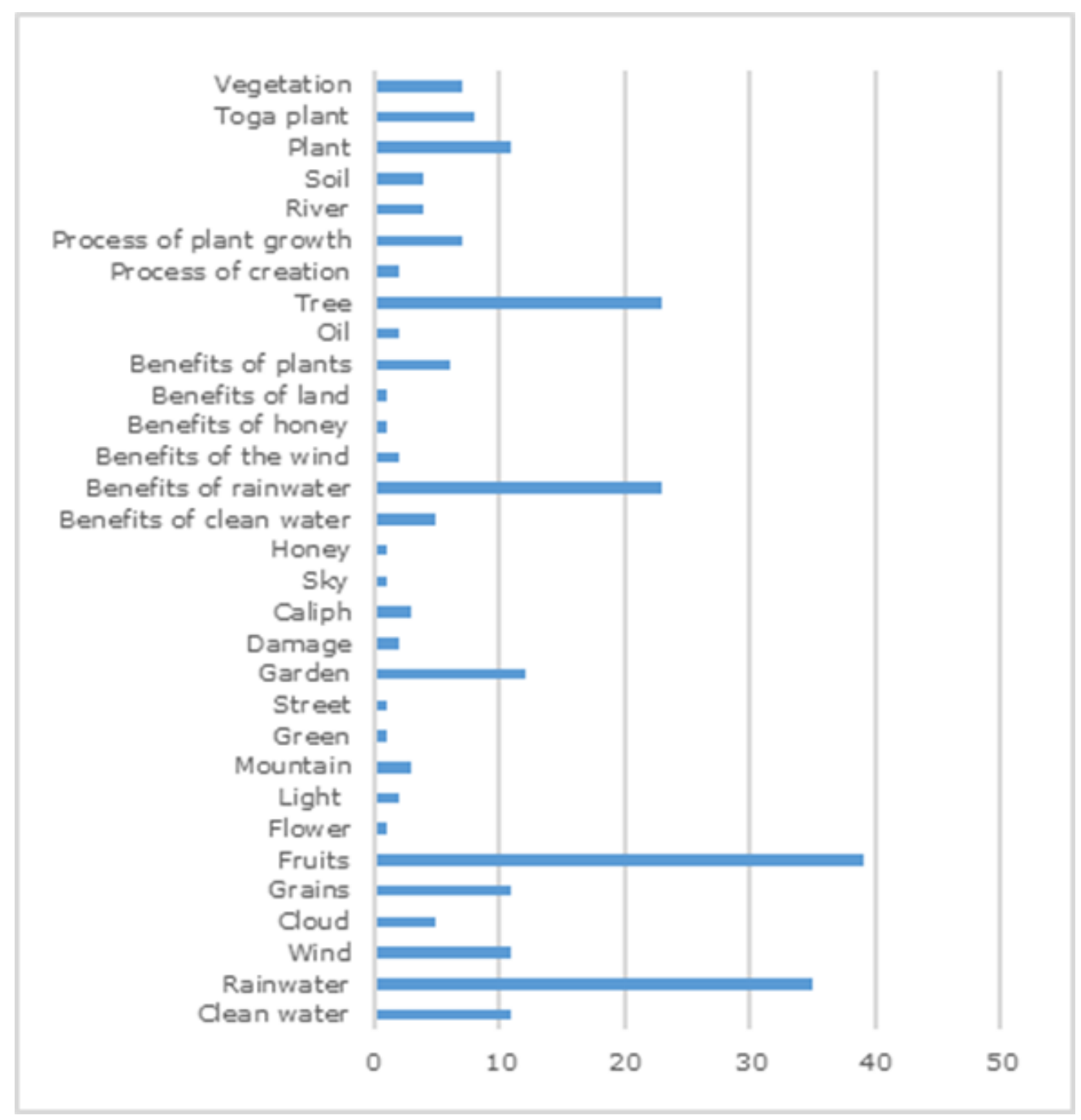

Figure 3. Keywords (Results of Content Analysis)

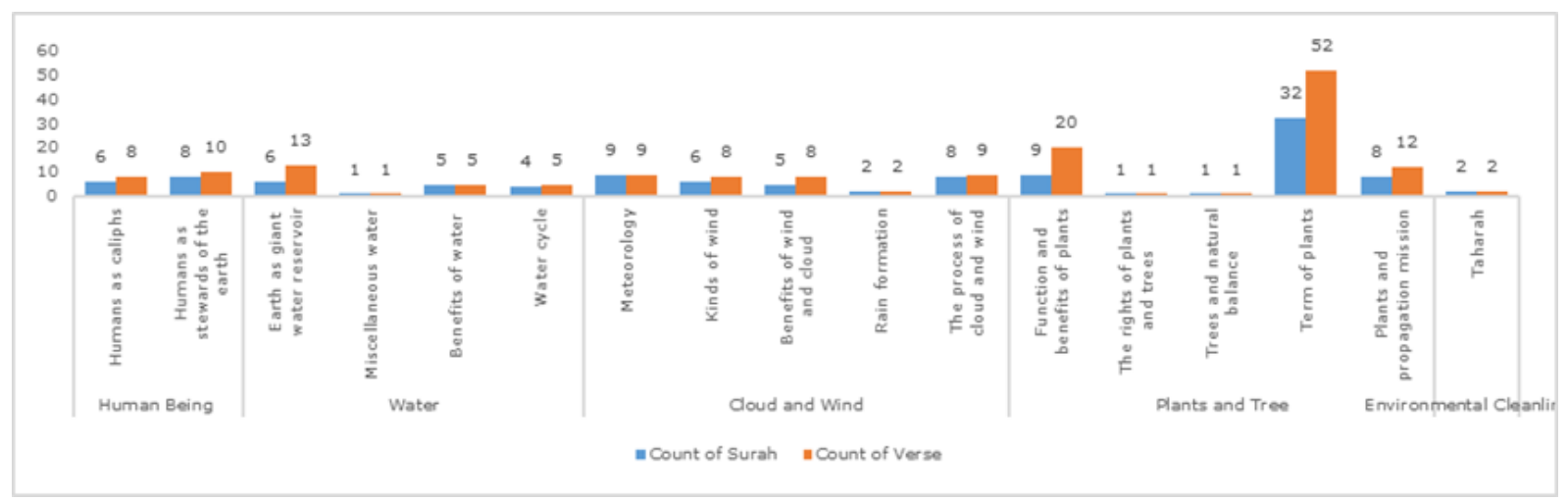

Figure 4. Keywords (Results of Content Analysis) 
THEMATIC TAFSEER AND GREENSHIP CATEGORIZATION IN GREENSHIP CRITERIA

Making the categorization of greenship is an attempt to interpret the Quran based on the thematic
Tafseer and is carried out to know more details. How each verse in the Quran describes greenship category is shown in figure 5 .

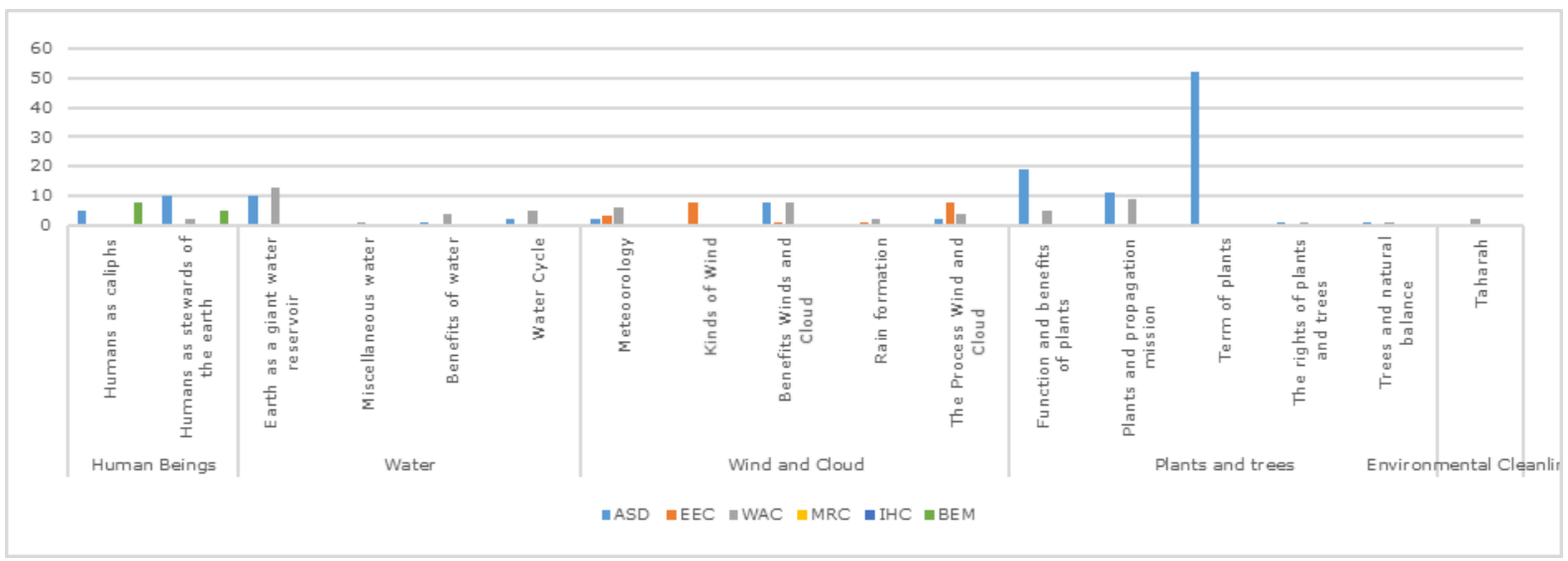

Figure 5. Categorization of Greenship based on the keywords from thematic Tafseer

The graphic above represents the two subthemes of Human as Caliph, and Human as Stewards of the earth, which put more emphasis on the ASD Criteria-Appropriate Site Development (15) followed by BEM-Building Environment Management points (13), and WAC-Water Points Conservation (2). It indicates that the site refers to "the earth" and its management, which become the responsibility of humans (Humans as caliphs and Humans as stewards of the earth). On the other hand, in Greenship discourse, the earth is interpreted as "land". Therefore, the Quran and Greenship emphasize the importance of planting plants and vegetation and landscaping on land to create green areas.

The sub-theme for "Water" emphasizes more on the WAC category, which is 23. It means that 23 verses explain the importance of Water Conservation. The biggest sub-themes support this through the explanation of "Earth as a giant water reservoir". The "Earth as a giant water reservoir" sub-theme is also associated with the ASD category, except for the subtheme "Miscellaneous water".

It is different from the previous two themes, which categorize only ASD and WAC for Wind and Cloud themes. Instead, it describes 3 Greenship categories named ASD (12), EEC (21), and WAC (20). Each surah and verse from the Wind and Cloud theme describes the categories of ASD, EEC, and WAC altogether by interpreting the interpretation of the Quranic verse.

In the sub-theme for "Plant and Trees", the compiled verses of the Quran focus more on the ASD category (84), and mostly emphasize on the "term of plants" sub-theme. The Quran often highlights the things related to plants and vegetation, both the name and the function. This is related to the existence of the earth as a place to plant, which will produce something needed by humans for their viability in the world. The sub-theme named "Plants and Trees" is also connected to the WAC category in several sub-themes, as explained in Al-Mu'minun (23):19 "And We brought forth for you the gardens of palm trees and grapevines in which for you are abundant fruits and from which you eat".

The sub-theme for "Environmental Cleanliness" emphasizes the WAC category ( 2 items), which illustrates the connection between purification (taharah) and water as one of the tools for purification. Meanwhile, there is no relation or connection found in other greenship categories. From all the data of verses and surah that have been organized, the greenship categorization is then formed. Table 3 and figure 7 gives a clear depiction that the Quran has its significant points to ASD (56.11\%), WAC (28.51\%), EEC (9.50\%), and the last is BEM (5.88\%). The order of concerns described in the Quran is also quite different from the Greenship category. In Greenship, the biggest interest is given to EEC (25.74\%) then WAC (20.79\%) and ASD (18.83\%), MRC (13.86\%), BEM (12.87\%), IHC (9.90\%). It indicates that Quran gives the greatest emphasis on the earth due to its function as the largest water storage source provided by heaven and earth as a place for the growth of grains, vegetables, and fruits as written in surah Abasa (80). The correlation between water, which is poured down from heaven and earth as the recipient, and the place to store the water, has been clearly illustrated in the Quran; all of which are aimed to fulfill human needs created by Allah, as written in Al An'am (6):99 and Al Anbiya '(21): 30. 


\section{GREENSHIP CATEGORIZATION BENCHMARK/RATING TOOLS}

The next stage is considering the relation between the Greenship criteria rating and the keywords of the Quran, which is derived from the thematic Tafseer. This stage is an attempt to see the rating in detail according to the thematic Tafseer so that it will be able to produce a complete and comprehensive Greenship framework, especially for the two most significant categories, namely ASD (56.1\%) and WAC (28.5\%), showing in figure 6.

\begin{tabular}{|c|c|}
\hline $\begin{array}{c}\text { Two significant } \\
\text { categories of } \\
\text { green building } \\
\text { based on thematic } \\
\text { interpretation }\end{array}$ & ADorooriate Site Develooment (ASD) \\
\hline
\end{tabular}

Figure 6. Significant Categories of Green Building Based on Thematic Tafseer

Table 1: Distribution of Greenship criteria benchmarks with keywords of the Quran derived from thematic Tafsee

\begin{tabular}{|c|c|c|c|}
\hline \multicolumn{4}{|c|}{ Appropriate Site Development (ASD) } \\
\hline Code & \multirow[t]{2}{*}{ Criteria } & \multicolumn{2}{|c|}{ Benchmark } \\
\hline \multirow{9}{*}{ ASD P } & & Softscape & 63 \\
\hline & \multirow{8}{*}{ Basic Green Area } & Vegetation & 53 \\
\hline & & Tree & 34 \\
\hline & & Shrubs & 23 \\
\hline & & Green & 1 \\
\hline & & Landscape & 5 \\
\hline & & Hardscape & 3 \\
\hline & & Clean Water & 6 \\
\hline & & Ground Water & 6 \\
\hline ASD 2 & $\begin{array}{l}\text { Community } \\
\text { Accessibility }\end{array}$ & Park & 6 \\
\hline \multirow{5}{*}{ ASD 5} & \multirow{5}{*}{ Site Landscapping } & Vegetation & 63 \\
\hline & & Green & 2 \\
\hline & & Soil Shape & 3 \\
\hline & & Clean Water & 6 \\
\hline & & Ground Water & 6 \\
\hline \multirow{2}{*}{ ASD 6} & \multirow{2}{*}{ Micro Climate } & Vegetation & 44 \\
\hline & & Micro Climate & 3 \\
\hline ASD 7 & $\begin{array}{l}\text { Storm Water } \\
\text { Management }\end{array}$ & $\begin{array}{l}\text { Rainwater } \\
\text { Management }\end{array}$ & 17 \\
\hline
\end{tabular}

Table 2: Criteria and Benchmark Based on Thematic Tafseer

\begin{tabular}{|c|c|c|c|}
\hline Code & Criteria & Benchmark & \\
\hline WAC P1 & Water Metering & Water Management & 22 \\
\hline WAC 1 & Water Use Reduction & $\begin{array}{l}\text { Clean Water } \\
\text { Consumption }\end{array}$ & 21 \\
\hline WAC 3 & Water Recycling & Water & 22 \\
\hline WAC 4 & $\begin{array}{c}\text { Alternative Water } \\
\text { Resource }\end{array}$ & Rainwater & 14 \\
\hline WAC 5 & Rainwater Harvesting & $\begin{array}{c}\text { Rainwater is one of } \\
\text { the sources of } \\
\text { water }\end{array}$ & 15 \\
\hline
\end{tabular}

In the ASD category in table 1 , the criteria that have conformity with the Quranic keywords and their relevance to the benchmark/rating tools are only five criteria, with one prerequisite criterion $(P)$ and four other criteria, namely ASD P, ASD 2, ASD 5, ASD 6 and ASD 7. It means that not all requirements are in accordance with thematic Tafseer. For example, if it is analyzed, the Basic-Green Area (ASD P) has nine benchmarks with the highest distribution in softscape (63), vegetation (53), tree (34), and shrubs (23). Meanwhile, the largest vegetation distribution benchmarks are on Site Landscaping (ASD 5), Basic Green Area (ASD P), and Micro Climate (ASD 6) criteria. Based on the data distribution, the P-Softscape ASD, ASD 5-Vegetation, ASD P-Vegetation, ASD 6Vegetation, ASD P-Tree, ASD P-Shrubs, and ASD 7Rainwater Management are the seven most identified benchmarks. Therefore, we conclude that the benchmarks of ASD in the Quran (thematic Tafseer) are mostly related to plants and vegetation and have met the prerequisite criteria.

In the WAC category on table 2, the criteria that are related to the benchmarks are only five criteria, with one prerequisite criterion (WAC P) and four other criteria, namely WAC 1, WAC 3, WAC 4, and WAC 5. It indicates that not all requirements are in accordance with the thematic Tafseer. The table below shows an almost even distribution of the five criteria with the highest distribution concerning the Water benchmark (22), Water Management (22), and Clear Water Consumption (21). In contrast, the next benchmark is related to rainwater. Based on the table, there are two main emphases, the use of clean water and rainwater. The efforts to conserve water are well-regulated and become a significant concern in the Quran, as mentioned in Surah Al-Anfal (8): 11 "[Remember] when He overwhelmed you with drowsiness [giving] security from Him and sent down upon you from the sky, rain by which to purify you and remove from you the evil (suggestions) of Satan and to make steadfast your hearts and plant firmly thereby your feet."

Both the ASD and WAC category tables have high distributions on the Greenship category, and the vegetation benchmarks are essential points for ASD $P$, ASD 5, and ASD 6 criteria. This illustrates that Quran emphasizes this benchmark and makes it a reference in creating Basic Green Area, Landscaping Site, and Micro Climate as shown in figure 8. Meanwhile, the benchmarks named softscape, shrubs, and tree also have a high distribution value for the ASD P criteria as an absolute criterion. Accordingly, based on this thematic Tafseer, Quran prioritizes the benchmarks on plants, as explained in Surah 'Abasa (80): 30 "And gardens of dense shrubbery."

Other significant points are related to water, such as groundwater, clean water, and rainwater, which are made as the benchmarks for the ASD and WAC Greenship criteria, as seen in figure 8. Rainwater is mentioned repeatedly in the Quran. Surah' Abasa (80) has mentioned: 25 " How We poured down water in torrents", so the management of clean water use is also an important point after plants. Figure 8 illustrates the importance of rainwater management and emphasis on how rainwater is one of the good sources of water for purification or other purposes. "([Remember] when He overwhelmed you with drowsiness [giving] security from Him and sent down upon you from the sky, rain by which to purify you and 
remove from you the evil [suggestions] of Satan and to make steadfast your hearts and plant firmly thereby your feet (Al Anfal (8): 11). Besides, Allah also reaffirms that the rainwater sent to earth will revive the fruits (Al -'Araf (7): 57), which is then supported by surah Al-
Anbiya (21): 30 "Have those who disbelieved not considered that the heavens and the earth were a joined entity, and We separated them and made from water every living thing? Then will they not believe?".

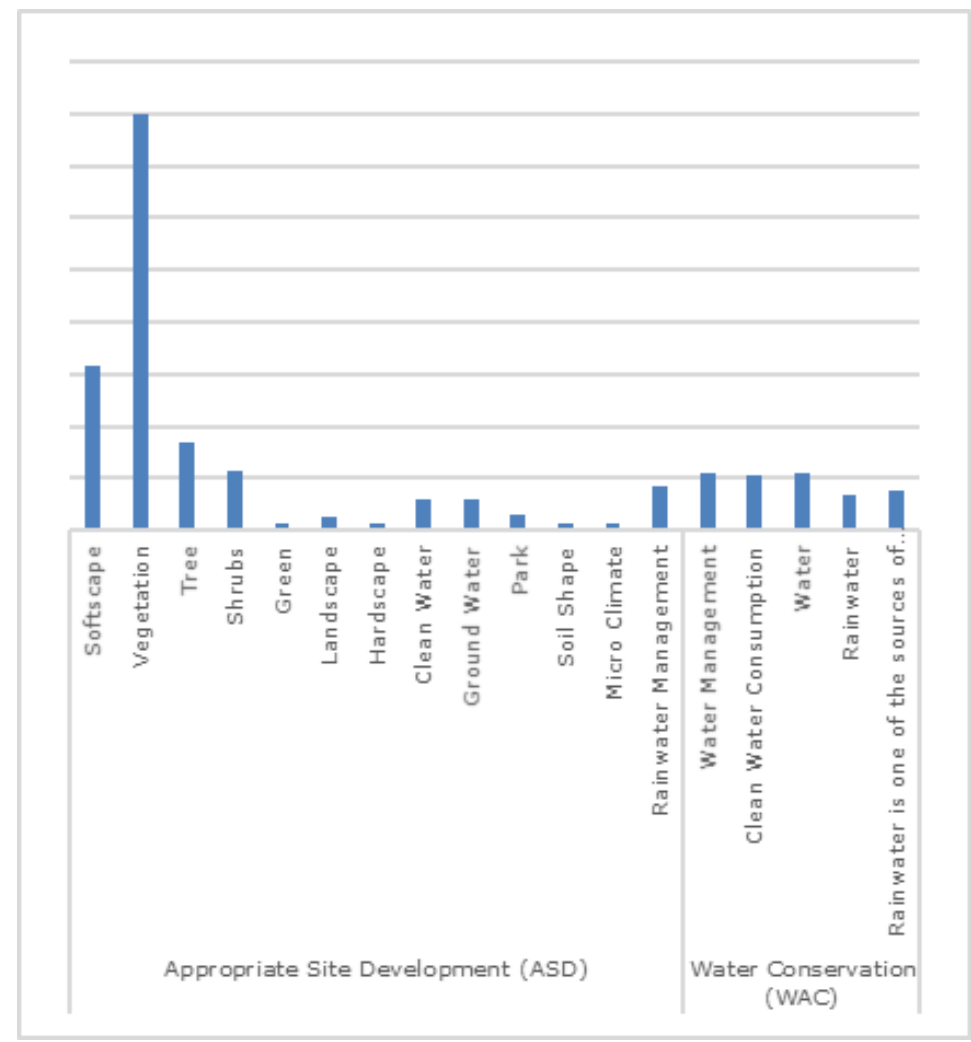

Figure 7: Distribution Criteria of Green Building Based on Thematic Tafseer

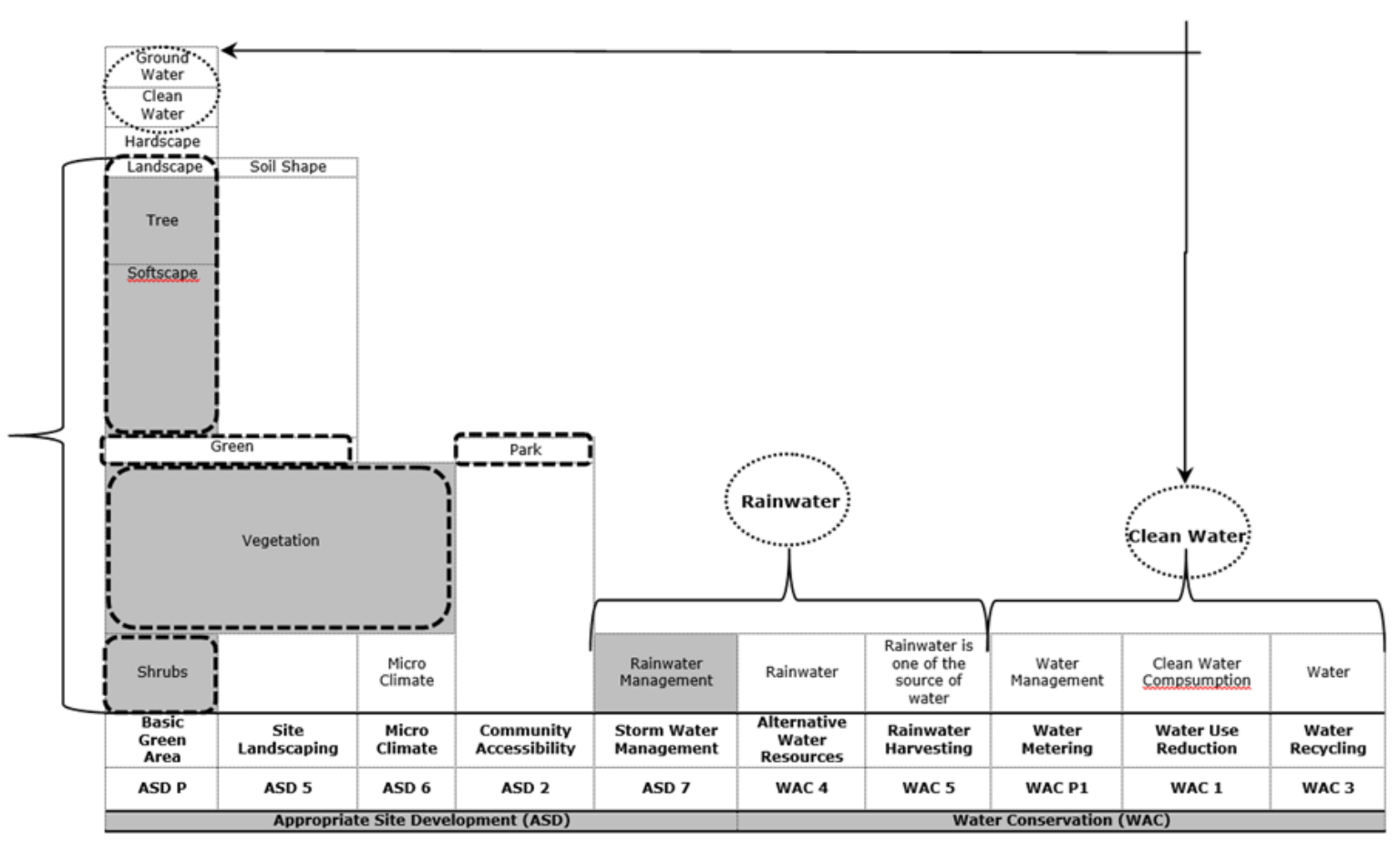

Figure 8: Significant Criteria of Green Building Based on Thematic Tafseer 
The concept of the green building based on thematic interpretation emphasizes two broad categories, namely ASD and EEC. The appropriate site management (ASD) and water (WAC) categories are vital for human survival on earth so that the protection of the natural environment is thriving. God provides the land and water for human life; in other words, humans are very dependent on processed products on the ground, so it was evident that the Qur'an governs plants, soft landscapes, and trees. Likewise, water has an indirect attachment to plants, where plants need water to survive to produce taller trees and produce fruit, leaves, and seeds entirely so that the results of these plants can be used by humans and living things to sustain life. It can be written here that the water here becomes a critical component that cannot be ignored. Also, it can be seen that there is a life chain that cannot be broken among water, proper site management, and living things, as written in the Quran surah Al An'am 99; " And it is He who sends down rain from the sky, and We produce thereby the growth of all things. We produce from it greenery from which We produce grains arranged in layers. And from the palm trees - of its emerging fruit are clusters hanging low. And [We produce] gardens of grapevines and olives and pomegranates, similar yet varied. Look at [each of] its fruit when it yields and [at] its ripening. Indeed in that are signs for a people who believe." This discussion can be continued by recalling the cues (instructions) of being associated with the significant presence of water, that Allah is hinting that there is underground water storage in Surah Al Hijr: "And We have sent the fertilizing winds and sent down water from the sky and given you drink from it. And you are not its retainers".

The ASD and WAC approach to make the environment sustainable becomes evident when we interpret the Quran written by Allah as a guide for humans. Also, the development of an appropriate location must hold the principle of land use with the carrying capacity and potential of the land so that sustainable land productivity can be achieved, including considering the aspects of conservation and environmental preservation for the future. Land management must be followed by applying landscape designs that strengthen the selection of plants, trees and living things. Appropriate site management to realize green building will provide extraordinary benefits for humans and environmental sustainability for the future. Strategic landscape design can certainly reduce the heat buildup and help the microclimate production that will ultimately reduce energy consumption. Furthermore, trees, grass, and bushes will also reduce the air temperature around the building and provide evaporative cooling [27].

Not only is site management the primary concern, but native plants is also needed to be maintained, considering that native plants can adapt better to drought conditions and pests. Besides, native plants, bushes, and trees can protect the biodiversity of an area better compared to areas planted with nonnative plants because non-native plants have their ecological system and they are quite safe for the surrounding biodiversity [28]. On the other hand, nonnative plants increase the need for water, so it will cause the local water supply running low. With a tendency for increased water needs, rainwater is the best solution to meet those needs. Thus, the Quran has also given instructions for utilizing rainwater as written in the An-Nahl: 10, "It is He who sends down rain from the sky; from it is drinking and from it is foliage in which you pasture [animals]." It means that rain, which is such clean water coming from the sky, should be a solution to make an environment come alive and provide life for creatures on earth. The explanation above can illustrate that the ASD and WAC categories are significant categories, both of which have interdependencies to make a life cycle on earth run entirely. Beside the criteria derived from the thematic Tafseer in the form of shrubs, trees, soft landscapes, vegetation and clean water, rainwater management are also essential points in developing green building concepts. The green building concept given by the Green Building Council Indonesia and the Green Building concept derived from Thematic Tafseer have different categories of emphasis (Table 3). The concept of green buildings derived from the thematic Tafseer is Islamic values that can be accepted and expected to be carried out properly by humans as the bearers of duties as caliphs on earth

Table 3. Comparison of Points Based on Greenship and Thematic Tafseer

\begin{tabular}{lcccc}
\hline \multicolumn{1}{c}{ Category } & Greenship & \multicolumn{2}{c}{$\begin{array}{c}\text { Greenshipbased on Thematic } \\
\text { Tafseer }\end{array}$} \\
\hline Appropriate Site Development (ASD) & 17 & $16.8 \%$ & 124 & $56.1 \%$ \\
2. Energy Efficiency and Conservation (EEC) & 26 & $25.7 \%$ & 21 & $9.5 \%$ \\
Water Conservation (WAC) & 21 & $20.8 \%$ & 63 & $28.5 \%$ \\
Material Resources and Cycle (MRC) & 14 & $13.9 \%$ & 0 & $0 \%$ \\
Indoor Health and Comfort (IHC) & 10 & $9.9 \%$ & 0 & $0 \%$ \\
Building Environment Management (BEM) & 13 & $12.9 \%$ & 13 & $5.9 \%$ \\
\hline
\end{tabular}




\section{CONCLUSION}

Islam provides comprehensive guidance for all aspects of life, including the environment. The Quran and Sunnah, as the primary and secondary sources of Islamic principles and values, provide the answers to all environmental problems. At the same time, they also show the proper relationship between humans and the environment.

There are two types of criteria in this category: prerequisite criteria and supporting criteria. The Land Use and Water Conservation requirement criteria have high marks. It indicates that these criteria must be completed to achieve a green building. In the Appropriate Land Use category, the Basic Green Area and Site Landscaping scored highly. In water conservation, the requirements for limiting the consumption of clean water and water recycling get the highest points because environmental quality is deteriorating due to uncontrolled urban expansion, converted green lands into structures, green foundation areas, and landscaping sites. Those are the vital factors that should become the requirements.

Without mechanics, green open space, landscaping patterns, and water management in the landscape are the finest ecological balancers. Green open space indicates that we protect the environment by maximizing what is currently available on our planet while improving the quality of life, human health and welfare. The availability of green open areas that promote air circulation and the ideal microclimate is supported by softscape, vegetation, trees, shrubs, clean water, and groundwater in the site. Keeping the site's shape is the foundation for creating a healthy and comfortable atmosphere.

Water conservation is also vital since the availability of clean water is an issue at the moment. Rainwater is frequently addressed in the Quran as a blessing from the sky and the land. The sprouting of plants that produce fruit is a blessing from the earth. Moreover, it is all because Allah shows His blessings through rain. We can see that rainfall has been delivered down to the soil with various benefits, one of which is using rainwater as a water supply, other than pure groundwater. Rainwater is sent down following its level to benefit His animals. God's creations must make the best use of what He has given.

\section{REFERENCES}

[1] R. J. Cole and A. Oliver, Low Energy Low Carbon Architecture Recent Advances \& Future Directions. London: CRC Press, 2016.

[2] T. Woolley and R. Harrison, Green Building Handbook: A Guide to Building Products and Their Impact on the Environment. New York: Spon Press, 2005.

[3] Y. Jabareen, "A New Conceptual Framework for Sustainable Development," Environ. Dev. Sustain., vol. 10, pp. 179-192, 2008, doi: 10.1007/ s10668-006-9058-z.
[4] J. Mensah, "Sustainable development: Meaning, history, principles, pillars, and implications for human action: Literature review," Cogent Soc. Sci., vol. 5, no. 1, 2019, doi: 10.1080/23311886.2019.1653531.

[5] R. L. Killawi, Sustainable Development from Islamic Perspective, 1st ed. Dubai: Islamic Affairs \& Charitable Activities Department, 2014.

[6] A. F. Muchlis, D. Larasati, and S. Sugeng Triyadi, "Sustainable Development and Architecture: A Conceptual Based on Religious Perspectives," Int. J. Adv. Res. Eng. Technol., vol. 11, no. 4, pp. 1-6, 2020, doi: 10.34218/IJARET.11.4.2020.001.

[7] A. Darko and A. P. C. Chan, "Critical analysis of green building research trend in construction journals," Habitat Int., vol. 57, pp. 53-63, 2016, doi: 10.1016/j.habitatint.2016.07.001.

[8] I. M. C. S. Illankoon, V. W. Y. Tam, K. N. Le, and L. Shen, "Key Credit Criteria Among International Green Building Rating Tools," J. Clean. Prod., vol. 164, pp. 209-220, 2017, doi: 10.1016/j.jclepro.2017.06.206.

[9] M. Ali, P. Miraj, and R. Windrayani, "Stakeholders' perspectives on green building rating: A case study in Indonesia," Heliyon, no. August 2018, p. e01328, 2019, doi: 10.1016/ j.heliyon.2019.e01328.

[10] Sahid, Y. Sumiyati, and R. Purisari, "The Direction of Developing Green Building Criteria in Indonesia," J. Phys. Conf. Ser., 2021, doi: 10.1088/1742-6596/1811/1/012090.

[11] A. F. Muchlis, D. Larasati, S. Sugeng Triyadi, Y. Hanifah, A. Wardhani, and N. Ekawati, "Development of Green Building Ranking Based on Stakeholders Values Using the AHP," IOP Conference Series: Earth and Environmental Science, vol. 738, no. 1, 2021, doi: 10.1088/1755-1315/738/1/012009.

[12] S. H. Alyami, "Critical Analysis of Energy Efficiency Assessment by International Green Building Rating Tools and Its Effects on Local Adaptation," Arab. J. Sci. Eng., vol. 44, No. 10, pp. 8599-8613, 2019, doi: 10.1007/s13369-01903972-x.

[13] Z. Gou and S. S.-Y. Lau, "Contextualizing green building rating systems: Case study of Hong Kong," Habitat Int., vol. 44, pp. 282-289, 2014, doi: 10.1016/j.habitatint.2014.07.008.

[14] H. H. Ali and S. F. Al, "Developing a green building assessment tool for developing 
countries - Case of Jordan," Build. Environ., vol. 44, no. 5, pp. 1053-1064, 2009, doi: 10.1016/ j.buildenv.2008.07.015.

[15] M. A. Khan, C. C. Wang, and C. L. Lee, "A Framework for Developing Green Building Rating Tools Based on Pakistan's Local Context," Buildings, vol. 11, no. 202, 2021.

[16] J. L. Wilson and E. Tagaza, "Green Buildings in Australia?: Drivers and Barriers," Aust. J. Struct. Eng., vol. 7 No 1, April 2006, doi: 10.1080/13287982.2006.11464964.

[17] A. Darko, C. Zhang, and A. P. C. Chan, "Drivers for green building: A review of empirical studies," Habitat Int., vol. 60, pp. 34-49, 2017, doi: 10.1016/j.habitatint.2016.12.007.

[18] H. Nguyen, M. Skitmore, M. Gray, and X. Zhang, "Will green building development take off?? An exploratory study of barriers to green building in Vietnam," Resour. Conserv. Recycl., vol. 127, no. May, pp. 8-20, 2017, doi: 10.1016/ j.resconrec.2017.08.012.

[19] M. Wimala, E. Akmalah, and M. R. Sururi, "Breaking Through the Barriers to Green Building Movement in Indonesia: Insights from Building Occupants," Energy Procedia, vol. 100, no. September, pp. 469-474, 2016, doi: 10.1016/ j.egypro.2016.10.204

[20] Y. Li, L. Yang, B. He, and D. Zhao, "Green building in China?]: Needs great promotion," Sustain. Cities Soc., vol. 11, pp. 1-6, 2014, doi: 10.1016/j.scs.2013.10.002.

[21] C. Jabbour, N. Kasai, and C. Jose, "Barriers to green buildings at two Brazilian Engineering Schools," Int. J. Sustain. Built Environ., vol. 3, pp. 87-95, 2014, doi: 10.1016/j.ijsbe.2014.05.004.
[22] W. D. T. Y. Li. T. Y.-T. Tang, "Barriers and policy recommendations for developing green buildings from local government perspective," Intell. Build. Int., vol. 10, no. 2, 2016.

[23] E. M. Ghazali, D. S. Mutum, and N. Ariswibowo, "Impact of Religious Values and Habit on an Extended Green Purchase Behaviour Model," Int. J. Consum. Stud., no. July, pp. 639-654, 2018, doi: 10.1111/ijcs.12472.

[24] A. H. Ansari, P. Jamal, and U. A. Oseni, "Sustainable Development: Islamic Dimension with Special Reference to Conservation of the Environment," Adv. Nat. Appl. Sci., no. January, pp. 607-619, 2012.

[25] M. Ebrahimi and K. Yusoff, "Islamic Identity, Ethical Principles and Human Values," Eur. J. Multidiscip. Stud., vol. 6, no. 1, p. 325, 2017, doi: 10.26417/ejms.v6i1.p325-336.

[26] Badan Litbang dan Diklat Departemen Agama RI, Tafsir Al-Qur'an Tematik: Pelestarian Lingkungan Hidup. Jakarta, 2009.

[27] A. Misni, "The Effects of Surrounding Vegetation, Building Construction and Human Factors on The Thermal Perfomance of Housing in A Tropical Environment," thesis, Victoria University of Wellington, 2012.

[28] H. Hoyle, J. Hitchmough, and A. Jorgensen, "Landscape and Urban Planning Attractive, Climate-Adapted and Sustainable? Public Perception of Non-Native Planting in the Designed Urban Landscape," Landsc. Urban Plan., vol. 164, pp. 49-63, 2017, doi: 10.1016/ j.landurbplan.2017.03.009. 